\title{
Prithvi Journal of Research and Innovation
}

[A Peer-Reviewed, Open Access Multidisciplinary Bilingual Journal; Indexed in NepJOL] ISSN 2705-4888 [Print]; ISSN 2705-4896 [Online]; JPPS Star-Rated Journal

Volume 3; 15 December 2021; pp. 69-81

eJournal Site: http://ejournals.pncampus.edu.np/ejournals/pjri/

ORIGINAL RESEARCH ARTICLE

\section{COVID-19 and Tourism in Pokhara: Strategies for Industry's Recovery}

\author{
Naresh Poudel ${ }^{1}$ \\ Rajeev Upadhyay ${ }^{2}$ \\ ${ }^{1,2}$ Department of Geography, Prithvi Narayan Campus, Pokhara
}

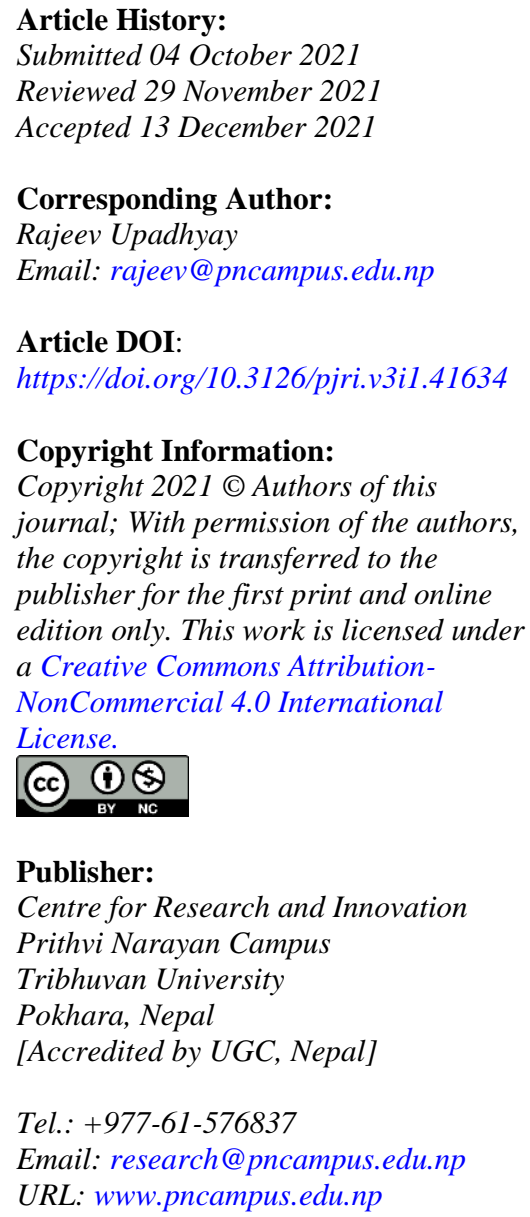

\section{ABSTRACT}

Tourism is considered as travel related activities. Pokhara has many attractions for tourists including lakes, hills, religious and cultural sites. The presence of Phewa Lake in the west, Begnas Lake in the east attracts a large number of domestic and international tourists. The main objective of this study is to explore the impact of COVID-19 on tourism of Pokhara. Altogether 120 samples were taken purposively in the major touristic areas of Pokhara. Interviews were taken with key informants and the observation technique was also used. The obtained data were discussed in the form of table, charts and figures. The number of tourists visiting Pokhara is found decreasing over the last two years due to the Covid-19 pandemic. High quality hotels are only in the Phewa Lake area whereas there are very few quality hotels in the study area, so quality hotels with better facilities should be established in other areas, too. New tourism activities need to be explored and after the operation of international airport, the option for the present paragliding spots need to be managed in time. To minimize the impact of Covid-19 pandemic, there should be a provision of easy refinancing facilities from the financial institutions to be provided to the tourism entrepreneurs, including subsidies on the equated monthly instalments and decreasing the interest rate and quick vaccination to the people involved in tourism sectors.

KEYWORDS: Tourism, infrastructure, attractions, COVID-19, refinancing

\section{INTRODUCTION}

Tourism is an activity related to travel that derives from the French word "tourisme". In 1910, Herman von Schulard gave the first definition of tourism, who is an 
Austrian economist. He gave the definition of tourism as "the sum of all total activities, mainly related to financial activities, which are completely related to full holidays and the movement of travellers". But today the term is defined differently. For instance, people within the country also travel as tourists known as domestic tourists. Therefore, tourism is the total sum of all kinds of phenomena and relations arising from the movement and accommodation of guests, as long as they do not lead to permanent inhabitants and are unrelated to any income activity. It is one of the world's leading and fast-growing industries (Neto, 2003). It is mainly a socio-cultural phenomenon defined by the consequences of people's travel and the temporary stay of people in places far from their normal habitat (Sherpley, 2014). Similarly, is also defined as a relationship between the environment and tourists. It is considered a social, cultural and economic experience that requires activities for market, business or many other purposes from more public places in other countries. For example, people in Nepal usually visit neighbouring countries like India for religious, health, or business purposes. Travelling not only means travelling from one country to another or outside the international border, but it can also be internal. This is useful for boosting the economy such as transport, integrated methods, food and drink and communication as the last stop of tourists is in isolated areas of the country. The progress of Nepal's travel industry plays an important role in the country's economic progress (Paudel \& Upadhyay, 2021). Nepal is the land of Mt. Everest, which is the highest mountain peak in the world, and the Lumbini is the birthplace of Gautam Buddha. Nepal has world's eight highest mountains among the 14 highest mountains in the world. It is also the best destination for mountaineers, rock climbers and adventure lovers, leisure, business, study, etc. There are many other important religious shrines across the country for the supporters of different communities and religions. Hindu, Buddhist and other cultural heritage sites are in Nepal, which act as an eye-catching object along with the annual tourist related festivals.

Tourism has both good and bad impact. The good impact is that it creates economic achievements through investment opportunities, which is an important source of foreign competition production as it is considered an easy way to create foreign exchange. The development of the tourism sector has also brought investment from abroad and helps to sell the local products. On the other hand, due to direct and indirect tourism employees make extra profits in the forms of tips, there are also "multiplier effects" which can have a prosperous impact on other business (Khand \& Maharjan, 2016). The affirmative influence, in addition to socio-culture, the environment and the economy, has a potentially a positive impact on the political development of destinations that have development opportunities for many countries and communities. Only if tourism development activities are regulated properly, there will be positive effects. If there is an extreme tourist movement then it can have adverse effects. When the earth's carrying capacity cannot handle with the flow of visitors which has a harmful impact on the environment and social space (Kayastha, 1997). For example, water supply, urban development, traffic jams and cultural and heritage sites can be destroyed with the maximum use of resources. Furthermore, tourism increases pollution through traffic emissions, waste, increased sewage production and noise. Trafficking of girls, kidnapping, drug abuse, animal hunting, terrorism and rape are some of the social issues that can occur in countries designated for tourism.

Agricultural products and remittances are the main support of Nepal's economy. The input in the agricultural sector is very high although the unbridled state of Nepali agriculture cannot be generated national supported economy due to mismanagement and still the practice of traditional methods. In this situation, tourism plays an important role in generating foreign exchange since the decade tourism has been well established as a 
leading industry in Nepal and has helped to grow the national economy. In the gross domestic product, the income of Nepal from tourism in 2018 was 7.9 percent and held more than 1.05 million investments, hoping to provide more than 1.35 million investment opportunities by 2029. In 2019, 1.19 million foreign tourists visited Nepal and the "VISIT NEPAL 2020" campaign, which officially launched on 1 January 2020 aimed to attract two million tourists in 2020 and end $\$ 2$ trillion and is expected to create thousands of new employers in the country (MOCTCA, 2019). The expected goal was unable to be achieved as the whole world as well as Nepal was severely affected by the COVID-19 pandemic. The entire country remained closed for months with the rest of the world and still the country's malfunctioning tourism industry. Disasters are of different nature and disasters are inevitable and their effects have also been on the tourism industry in Pokhara (Chaudhary, 2019).

Pokhara is a city with various types of natural beauties, with a view of lots of snow-covered mountains, lakes and waterfalls, and rich places of hospitality and culture. It is located at a height of $827 \mathrm{~m}$. above the sea level. It has nine lakes and the three highest mountains in the world such as Annapurna I (8091 m.), Dhaulagiri $(8167 \mathrm{~m}$.) and Manaslu $(8164 \mathrm{~m}$.), which can be easily viewed from Pokhara. It is in the northern part of the valley, the gorge of Seti River, Karst Caves, Seti River system and also the city is equipped with amazing Davi's Fall. It is the major crossroad connecting Nepal's main hiking and climbing routes. The journey to Annapurna trek, trek to the base camp of Annapurna, Ghorepani Punhill, Mardi Himal, Dhampus Village Trekking, Millennium Trekking, and Upper Mustang Trekking are the top trekking routes that starts from it where anybody can love the view of diverse foothills and peaks of the mountains closely. It is a metropolitan city rich in all types of natural attractions, famous snow-clad mountains, Lakes and waterfalls and hospitality and culture.

Almost all the tourists travelling from Kathmandu to Pokhara use road or air transport as the main means of transport. Phewa Lake, a tourist hub, is the heart of Pokhara and it is next to the bus station and the airport. Most visitors and locals are interested in using buses, minibuses, taxi, etc. as a mode of transport, which is a rational and the easiest means of transport. Tourists also use tourist buses for sightseeing, which is luxurious and expensive (Paudel \& Upadhyay, 2021).

In around 1950 and 1960, Pokhara was discovered as a transit point for mountaineering. In1962, several thousand tourists explored the place. It became popular in the outside world when French national Maurice Herzog and his group climbed Mt. Annapurna I on 3 June 1950. In 1966, Colonel Jimmy Roberts along with Thomas Cook (Father of the Travel Agency) began professional tourism, which is considered a milestone in the history of Nepal's tourism industry. It was also considered the best place for Western hippies during the 1960s and 1970s. These hippies were explorers of new countries around Pokhara during that period and after that period the tourism industry began to grow in this place (Upreti, Upadhyaya \& Saptkota, 2013).

The Covid-19 spread was stated as pandemic by WHO, which is known as the coronavirus pandemic. Its scientific name is SARS-CoV-2 virus, which was first noticed in Wuhan, China in December 2019. Though the first initial case of COVID-19 imported to Nepal was found on 23 January 2020. In response to the rapid rise in global measures and increasing public concern, the government postponed the "VISIT NEPAL 2020" on 3 March the same year. When WHO declared the COVID-19 pandemic on 13 March 2020, Nepal government adjourned all permissions for mountaineering operations and suspended all visas in Nepal. After the second imported case that was confirmed on 23 March 2020, the government imposed the nationwide lockdown and restricted all the national and international flights. The international and domestic tourism fell down in January 2020 
after tourist arrivals fell to Ztwo percent compared to 2019. Nearly 10,000 tourists who entered Nepal before the lockdown were also stuck though many of them were eventually deported. Remittances from 3.5 million Nepali living and working overseas made up about a one-fourth of the country's GDP (Adhikari, 2019).

It has been found that four different types of crises faced by tourism entrepreneurs and tourism workers during the COVID-19 crisis in the country as well as in Pokhara. They are economic crisis, like poverty, unemployment, debt (Paudel \& Upadhyay, 2021). Kim, J. H. and Richie (2014) said that "various tourism researchers have called for proactive crisis response and management plans founded on knowledge from SARS"; though Jamal and Budke (2020) did not respond to an active crisis over the COVID-19 epidemic and showed their view that inappropriately, integrated disaster management and announcement plans are rarely implemented efficiently at the local community, provincial or country level. The city of Pokhara is now vacant due to the COVID-19 pandemic. Since it is a tourist centre that attracts visitors from all over the world and even Nepal, residents fear that those visitors have brought the COVID-19 virus with them and, therefore, have not left their homes. It also means that the lively tourism city is now empty.

Against this backdrop, this study not only paved the ways for the economic recovery, broadcasting management and publicity but also for the sustainable development of tourism in Pokhara during the COVID-19 pandemic. The COVID-19 impact had a direct influence on the tourism business in the city.

\section{METHODOLOGY}

This paper aims to explore the impact of COVID-19 pandemic on tourism of Pokhara. The study is based on qualitative approach. It explains the current pandemic crisis on tourism activities in the city. The study has provided the information for future tourism management.

Basically, this paper depends on the primary sources. The information was collected purposively in the major touristic areas of Pokhara. Altogether 120 samples were taken; out of which 43 were hotels and restaurants, 24 curio shops, 19 garments shops, six puja samagri shops and remaining 28 were tea shops and others. For the secondary data, information were taken from the published and unpublished documents of the government, INGOs, NGOs and private organisations, books and journals from the library and related websites on the Internet.

A questionnaire was prepared for the purpose of collecting information for the study. Along with the questionnaire, interviews with key informants and observations techniques were also used. The observation technique was used to find out the impact of COVID-19 pandemic on the major touristic areas of Pokhara. Both openended and closed-ended questionnaires were designed to know the impacts of COVID-19 pandemic on tourism of Pokhara. The questionnaires were distributed to the hoteliers, restaurants and tourism entrepreneurs. The collected information was examined both qualitatively and quantitatively. The obtained data were discussed in the form of tables, charts and figures.

Pokhara is located in the Kaski district of Gandaki Province, which is in the lap of the Annapurna range. It is situated between $28^{\circ} 04^{\prime} 10^{\prime \prime} \mathrm{N}$ to $28^{0} 20^{\prime} 30^{\prime \prime}$ north latitude $83^{\circ} 48^{\prime} 40^{\prime \prime} \mathrm{E}$ to $84^{0} 09^{\prime} 50$ "E longitude. In terms of area, it is the largest city in Nepal, covering an area of 464.24 sq.km. It extends from $418 \mathrm{~m}$ (confluence of Kotre Khola and the Seti River) to $2115 \mathrm{~m}$. It is known as the Lake City that includes the famous lakes like Phewa, Bagnas, Rupa, Khaste, Dipang, Maidi, Niyureni, Gunde and Kamalpokhari that attract a large number of tourists each year. It is also considered a tourist headquarter of Nepal. Madi and Rupa Rural Municipality are located to the east of Pokhara, to its west 
lays the Annapurna Rural Municipality, and Parbat and Syangja districts, to the north lays Machhapuchhre and Madi Rural Municipality and to its south lay Syangja and Tanahun districts (figure 1). It was declared as a Metropolitan City in 2016.

\section{Figure 1}

Study Area

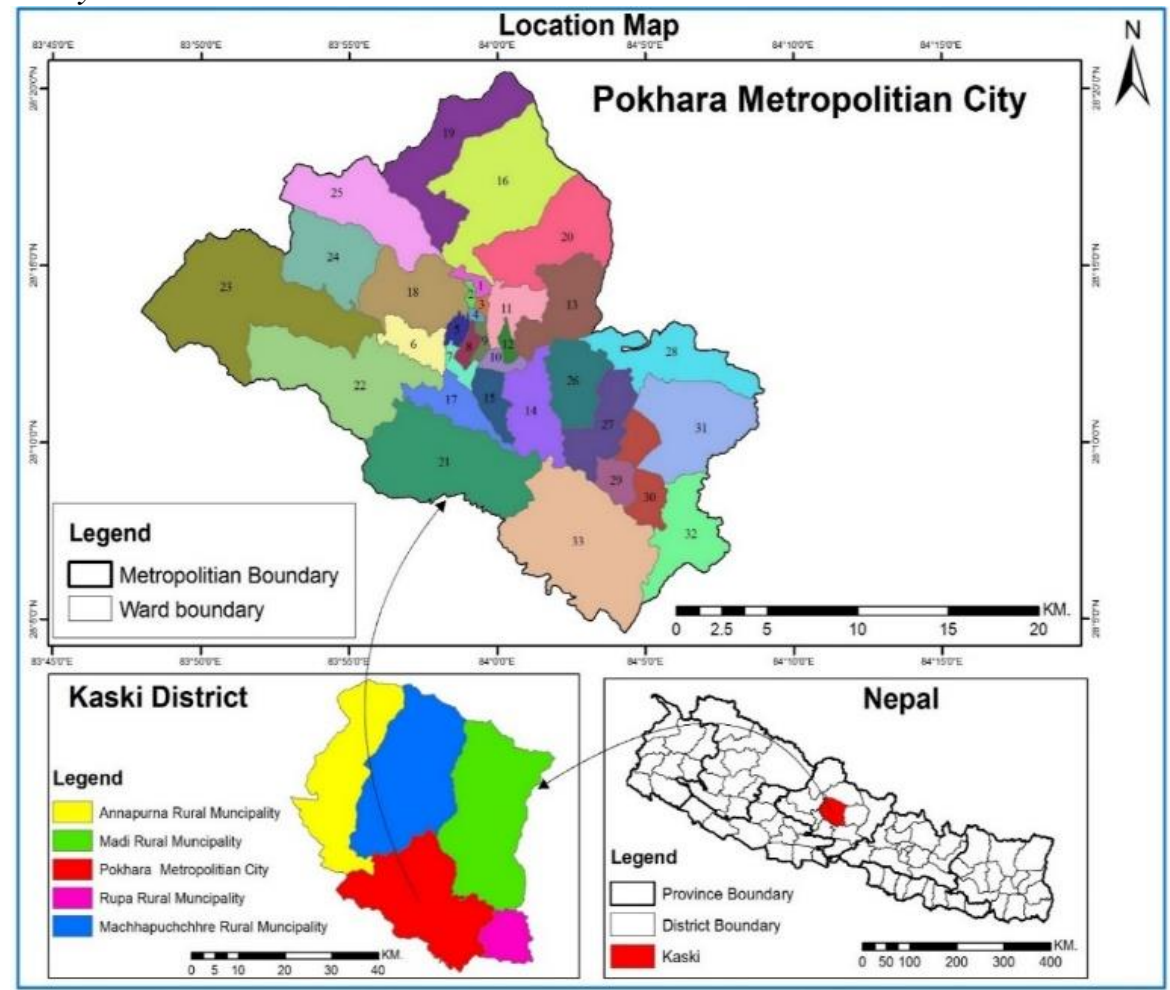

\section{RESULTS AND DISCUSSION}

Pokhara is a naturally beautiful city located in the central part of the country. There are many tourist areas in the city, including the shores of Phewa Lake, Sarangkot, Begnas Lake, Chhorepatan, Shanti Stupa, Bindhyabasini, Khapaundi, Mahendra Cave and many other locations. This paper also describes the tourism infrastructure available in these areas, including tourism activities. The impact of the pandemic on tourism is described along with positive and negative results. The main discussion was on the impact of the COVID-19 pandemic on tourism in Pokhara.

\section{Tourism Infrastructures}

For the development of tourism, infrastructure plays an important role. Pokhara being a touristic hub has provided different tourist services. It is well equipped with road networks, better security facilities along with medium and cottage industries. It has been found that include 109 tourist buses, a domestic airport, a tourist bus park, 4800 taxis, 885 boats (785 in Phewa Lake and 135 in Begnas Lake), 592 hotels of international standards such as two 5-stars, five 3-stars, fifteen 2-stars and 272 tourist restaurants, 116 trekking agencies, 124 restaurants and bars, 11 dance bars and nightclubs, and 18 paragliding agencies. In this regard, tourism industry currently has been providing several services like trekking equipment and clothing stores, parks and grounds, and transport services, trekking equipment's and clothing stores, boat clubs, book stalls, money changers and others (Paudel \& Upadhyay, 2021). 


\section{Major Attractions of Tourism}

Pokhara is potential for natural beauty, socio-cultural space and pleasant climate. Trekking, rafting, kayaking, paragliding, bungee jumping, mountaineering, hiking, sightseeing, views from Sarangkot, boating in Phewa Lake and Begnas Lake are the major activities. Other attractions include temples, caves, tours, forests, waterfalls, terraces and many other activities. Phewa Lake is famous for boating and Tal Barahi Temple is located within the lake. Begnas Lake is another lake situated in the eastern part of the city, which is also famous for boating and other recreation activities. The city is also famous for religious and cultural tourism. Brahmin, Chhetri, Gurung, Magar and Newar are different ethnic groups. People follows Hinduism, Buddhism,Islam, Christianity, and so on. Other temples like Bindhyabasini, Bhadrakali and Kedareswor attract Hindu pilgrimages and the Shanti Stupa is the holly place for the Buddhist pilgrimages. Apart from this there is mountain museum equipped with all sorts of mountaineering equipment's.

\section{Major Tourism Spots}

The major tourism activities available in Pokhara are trekking, hiking, bungee jumping, cannoning, rafting, boating, kayaking, paragliding, mountain flight, bird watching, rock climbing, zip flyer, mountaineering, museum observation, cycling, scenic view, mountain biking, rough road driving, marathon, feast and festivals and the major tourism spots are shown in the map (Figure 2).

\section{Figure 2}

Touristic Areas and Activities

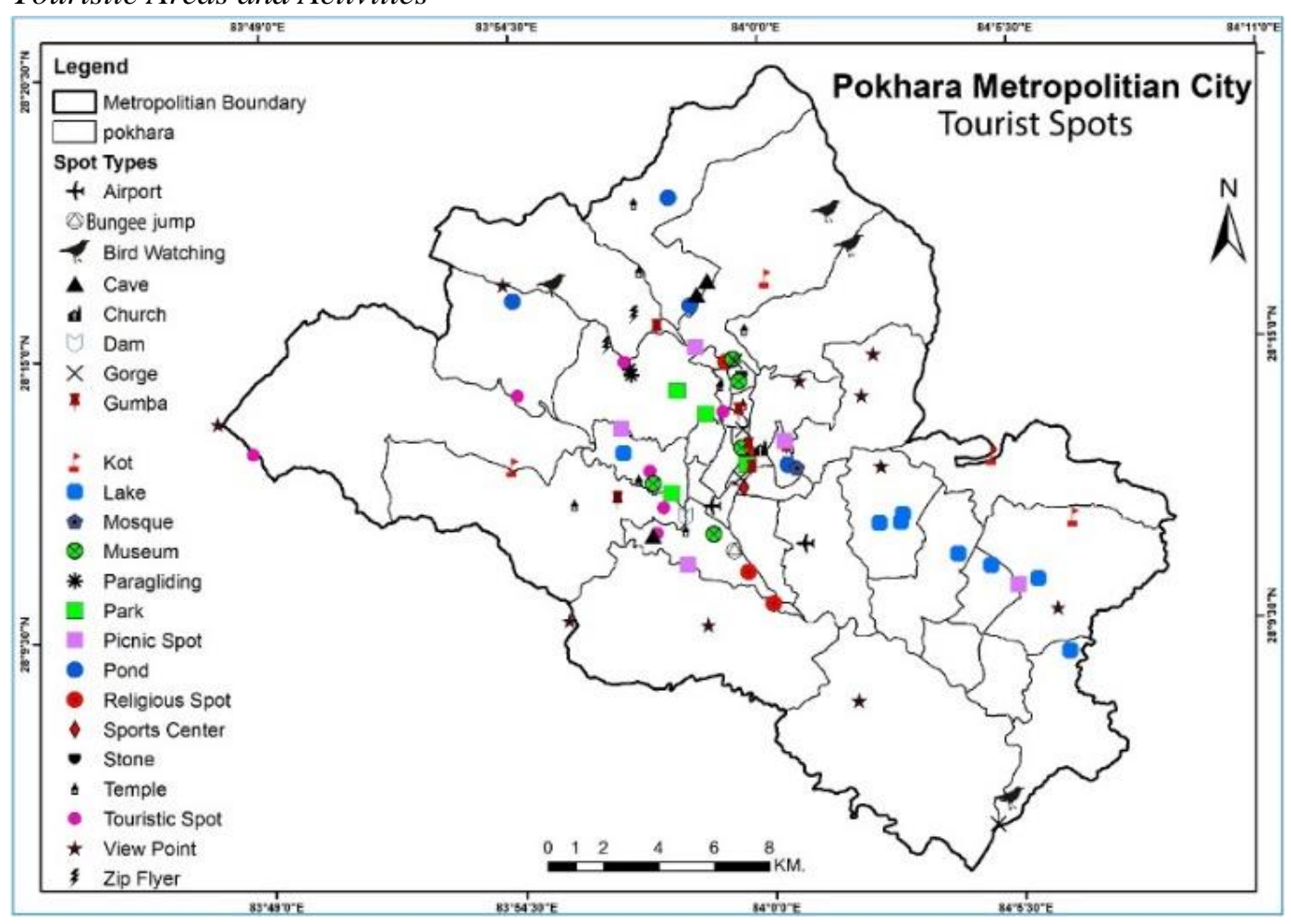

\section{Status of Tourism}

A particular destination has a significant economic, socio-cultural and environmental impact. The effect can be both negative and positive. In addition, tourism has produced a large number of positive economic results by creating the highest level of 
foreign exchange earnings and employment opportunities. In addition, well-run tourist destinations have potential positive implications and play an active role in boosting the economy, socio-cultural and environmental context. On the other hand, when there are uncontrolled tourism activities, there may be negative effects on different aspects. It has a bad effect on a particular location when nature cannot control the flow of tourists. Furthermore, a well-managed and accurate examination of tourist activity and tourist flow help in the outcome of actual mechanism and strategy to reduce negative effects (Paudel \& Upadhyay, 2021). Tourism has increased employment opportunities. Additional jobs, from low-wages to well-paid specialized positions in administration and technology, produce earnings and increase living standards for those in the tourism profession. This study was based on the major touristic areas, which are classified according to the flow of tourists on a regular basis. Phewa Lake, Sarangkot, Begnas Lake, Chhorepatan, Shanti Stupa, Bindhyabasini Temple, Mahendra Cave, and Khapaundi are the major places, which attract tourists of different types. Various types of small and big businesses associated with tourism have been found in the study area (Table 1).

Table 1

Types of Business in the Study Area

\begin{tabular}{llllll}
\hline Tourist Area & $\begin{array}{l}\text { No. of Hotels } \\
\text { and } \\
\text { Restaurants }\end{array}$ & $\begin{array}{l}\text { Curio } \\
\text { Shops }\end{array}$ & $\begin{array}{l}\text { Puja } \\
\text { Samagri } \\
\text { Shops }\end{array}$ & $\begin{array}{l}\text { Garment } \\
\text { Shops }\end{array}$ & $\begin{array}{l}\text { Tea Shop } \\
\text { and Others }\end{array}$ \\
\hline PhewaLakeside & 1425 & 400 & 12 & 76 & 76 \\
Sarangkot & 25 & 10 & & 11 & 28 \\
BegnasLake & 26 & 6 & & 4 & 30 \\
Chhorepatan & 7 & 54 & 10 & 28 & 25 \\
Shanti Stupa & 24 & 3 & & 6 & 14 \\
Bindhyabasini & 2 & 14 & 21 & 8 & 22 \\
Mahendra Cave & 4 & 18 & & 5 & 18 \\
Khapaundi & 65 & 12 & & 10 & 32 \\
\hline Total & $\mathbf{1 5 7 8}$ & $\mathbf{5 1 7}$ & $\mathbf{4 3}$ & $\mathbf{1 4 8}$ & $\mathbf{2 4 5}$ \\
\hline
\end{tabular}

Source: Respective Ward Office, Pokhara Metropolitan City, 2021

Table 1 shows the number of hotels and restaurants more in Phewa Lake area, Khapaundi, Begnas Lake and Sarangkot respectively. Shanti Stupa, Bindhyabasini, Chorepatan and Mahendra Cave have only few restaurants and curio and garment shops. Being a religious place, the area of Bindhayabasini Temple has a greater number of puja samagri shops. Phewa Lake has 76 garments shops where different types of seasonal garment including foreign garment are found. A number of curio shops is more in the areas of Phewa Lake, Chhorepatan, Mahendra Cave and Bindhyabasini Temple respectively. The local people in the Begnas Lake area and Shanti Stupa, Sarangkot, Khapaundi and in the Phewa Lake area are involved in tea shop business and other activities as well. Table 2 shows the involvement of the people in different types of business related to tourism less than five years to more than 20 years.

Table 2

Business Operation in Years

\begin{tabular}{llllllll}
\hline Areas & \multicolumn{7}{l}{ Years of Operation } \\
\cline { 2 - 8 } & $<\mathbf{5}$ & $\mathbf{5 - 1 0}$ & $\mathbf{1 0 - 1 5}$ & $\mathbf{1 5}-\mathbf{2 0}$ & $\mathbf{2 0}$ & Total & Percent \\
\hline PhewaLakeside & 4 & 9 & 8 & 9 & 12 & 42 & 35.00 \\
\hline \multicolumn{8}{l}{ Prithvi Journal of Research and Innovation }
\end{tabular}




\begin{tabular}{llllllll} 
Sarangkot & 3 & 2 & 2 & 1 & 2 & 10 & 8.33 \\
BegnasLake & 5 & 2 & 1 & 3 & 1 & 12 & 10.00 \\
Chhorepatan & 4 & 3 & 4 & 2 & 2 & 15 & 12.50 \\
Shanti Stupa & 3 & 2 & 2 & 0 & 0 & 7 & 5.83 \\
Bindhyabasini & 3 & 1 & 4 & 2 & 1 & 11 & 9.17 \\
Mahendra Cave & 5 & 3 & 2 & 1 & 1 & 12 & 10.00 \\
Khapaundi & 4 & 6 & 1 & 0 & 0 & 11 & 9.17 \\
\hline Total & $\mathbf{3 1}$ & $\mathbf{2 8}$ & $\mathbf{2 4}$ & $\mathbf{1 8}$ & $\mathbf{1 9}$ & $\mathbf{1 2 0}$ & $\mathbf{1 0 0 . 0 0}$ \\
\hline
\end{tabular}

Source: Field Survey, 2021

Table 2 reveals that 35 percent respondents are from the Phewa Lake area. 12.50 percent is from Chhorepatan and Begnas Lake. Similarly, Mahendra Cave has 10 percent each, 9.17 percent of Bindhyabasini and Khapaundi and Sarangkot has 8.33 percent. In Shanti Stupa, the number of respondents is 5.83 percent. 31 respondents had started tourism business before five years, 28 of them started their business in between 5-10 years, 24 of them started their business from 10-15 years ago. The number of people who started their business in between 15-20 years ago is 18 while only 19 respondents were found doing their business before 20 years.

\section{Impact of COVID-19 on Tourism}

Pokhara was considered one of the best destinations for the Western tourists during the 1960s and 1970s, and the Europeans were the first explorer to visit the Annapurna region of Pokhara. French citizen Maurice Herzog and his group of mountaineers scaled Mount Annapurna I $(8,091 \mathrm{~m})$ on 3 June 1950. Since then, it has become the gateway to the Annapurna region. Its surrounding districts attracted 298,975 international and 600,000 domestic tourists in 2018, generating NRs. 30 billion or 10 percent of the Gandaki provincial GDP (Prasain, 2021). Tourism industry is the largest enterprises in Nepal. In 2018, the country's domestic product accounted for 7.9 percent of the total gross domestic product and has provided more than 1.05 million jobs. The government has also aimed of offering more than 1.35 million jobs by 2029. It has been estimated to present 1.19 million foreign tourists in 2019, and the "VISIT NEPAL 2020" campaign, which was officially launched on 1 January 2020, aiming at attracting two million tourists in the same year by generating two billion dollars and creating thousands of new job opportunities (Dhakal, 2019).

Pokhara is Nepal's major tourism destination. There are more than 1500 hotels and restaurants in the city. It is one of the high-profiled cities of Nepal. In 2018, it paid revenue of 7.9 percent of the income. It served two million of tourists, created a new business with $\$ 2$ billion (NTB, 2018). In 2020, the COVID-19 pandemic lost its transmission and tourism income has decreased the country's economy to a large extent due to two phases of lockdown in the year 2020 and 2021. The pandemic has worsened the travel industry in the city.

\section{Impacts of COVID-19 on Hotels and Restaurants and other Business}

The outbreak of COVID-19 has restricted the flow of tourists in Nepal. The tourism entrepreneurs have closed their business as the first case was seen in Nepal on 23 January 2020. After the first wave of COVID 19, the number of tourists' arrival in Pokhara decreased. The first lockdown has affected the business. Table 3 reveals that 32.56 percent of hotels remained closed for more than a year. Similarly, 25.58 hotels are still closed, 2.33 percent of hotels did not remain closed even during the pandemic period. 
Table 3

Business Affected by COVID-19 Pandemic

\begin{tabular}{lll}
\hline Duration & No. of Hotels & Percent \\
\hline Not at all & 1 & 2.33 \\
1-5 Months & 6 & 13.95 \\
5-9 months & 11 & 25.58 \\
More than a year & 14 & 32.56 \\
Still Closed & 11 & 25.58 \\
\hline Total & 43 & 100.00
\end{tabular}

Source: Field Survey, 2021

Pokhara Metropolitan City gave permission for the business operation after August 2020. Before the permission was granted by the local government, a few hotels and restaurants have provided quarantine and take away services. This service took place only in the Phewa Lake area. Table 4 shows the number of hotels and restaurants providing service of quarantine and take away services.

Table 4

New Business Models to Bring in Income during the Pandemic

\begin{tabular}{lll}
\hline Services & No. & Percent \\
\hline Used as quarantine & 2 & 4.65 \\
Take away facility & 14 & 32.56 \\
Catering services & 4 & 9.30 \\
Closed & 21 & 48.84 \\
Other & 2 & 4.65 \\
\hline Total & $\mathbf{4 3}$ & $\mathbf{1 0 0 . 0 0}$ \\
\hline
\end{tabular}

Source: Field Survey, 2021

Table 4 shows that 4.65 percent of hotels in Pokhara were used as quarantine, 32.56 percent of them provided take away facility, 9.30 percent of them earned with catering services, 48.84 percent hotels remained closed and 4.65 percent hotels provided with other facilities. According to the District Covid-19 Crisis Management Center, Kaski (DCCMC), the reports of 2020 provided permission to operate 12 hotels of Phewa Lake. Only two hotels (Hotel Temple Tree and Hotel Dahlia) were used as quarantine. The hotels which have got the facility of quarantine were also not effectively operated. As the DCCMC meeting provided flexibility on lockdown, the tourism entrepreneurs in Pokhara requested the administration and government that they would be able to open their businesses if relief programmes were provided along with vaccination. According to the tourism entrepreneurs of Pokhara, if the government does not provide vaccines, they have to hand over their business to the government with a slogan "NO VACCINE, NO TOURISM" whereas the government has provided them with the refinancing aid for the tourism entrepreneurs on the first COVID-19 impact in Pokhara (Figure 3). 


\section{Figure 3}

Status of Refinancing Aid

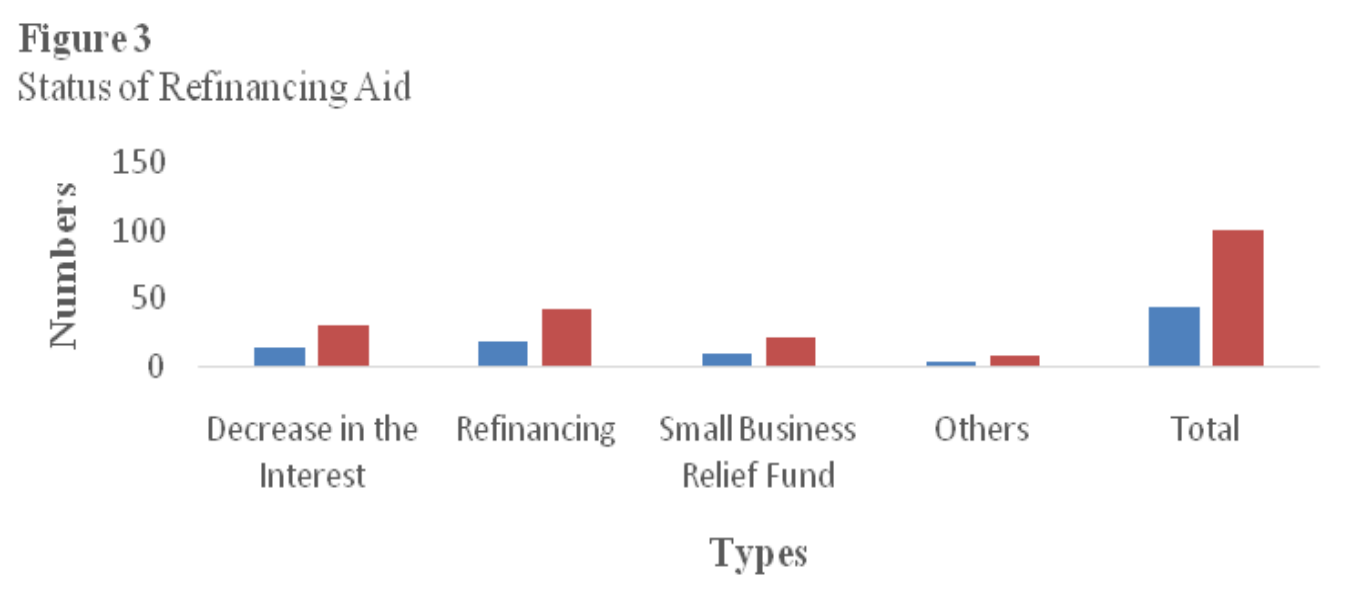

Figure 3 shows that the banks where the hotel and restaurant entrepreneurs have taken out a loan for the company where 30.23 percent have got the facilities to reduce the interest rate on the loan and 41.86 percent are included in the refinancing, 20.93 percent hotels have an auxiliary fund for small businesses and 6.98 hotels are included in other types of grants.

The other types of businesses like curio shops, puja samagri shops, garment shops, tea shops and others were also highly affected. They also remain closed during the lockdown period. They stated that they were not supported financially from any organization. They also cut off the workers and their main demand is to provide vaccine and they should get permission to open their business soon.

The Pokhara Tourism Council also claimed for a swift implementation of the monetary policy introduced by Nepal Rastra Bank last year, as it has yet to be implemented. In a press release, the Pokhara Tourism Council urged the Nepal Government to immediately implement the economic policies and programme announced in the 2020 and 2021 budgets. Other business operators also claim that the provincial and the federal government should ease financial institutions to bear bank interest and rent of their shops during the lockdown period. Likewise, the key informants such NTB, HAN, PTC, REBAN, NATTA, TAAN, etc. have suggested the following measures to boost up the tourism industry of Pokhara during this crisis:

- Facility of easy refinancing from the financial institutions.

- Facility of subsidies in the Equated Monthly Installment (EMI)in the loan.

- Provision of free health facilities to the tourism workers

- Relief of taxes in the business of the lock down period.

- Operation of domestic flights

- Subsidies on the rent by the house owners.

- Vaccination to the tourism enterprises and workers.

The study also found that the tourism entrepreneurs have cut off the workers after the COVID-19 pandemic as it pushed them to close the tourism business for a longer period of time followed by two consecutive lockdowns in two years.

\section{Figure 4}

No. of Workers Affected by the Lockdown

Prithvi Journal of Research and Innovation 


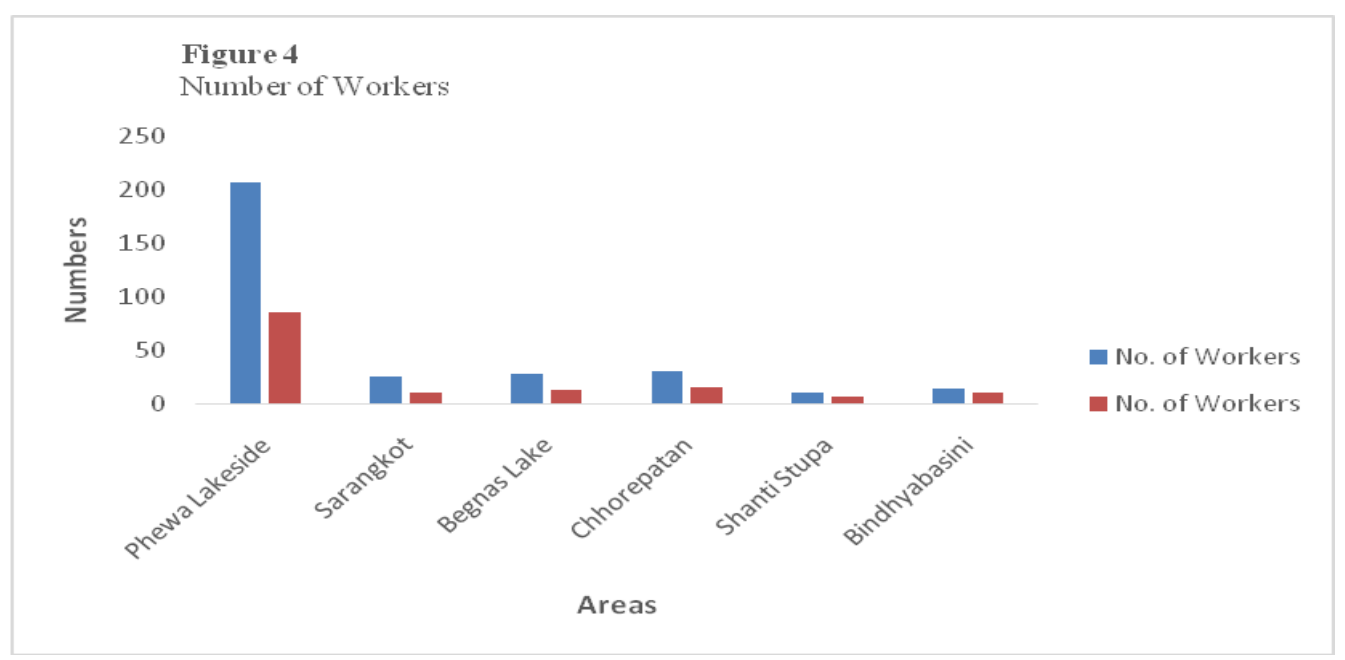

The hotels and restaurants owners have largely cut off the workers. A large number of workers were cut off at Lakeside area. Out of 207 workers before COVID-19 pandemic was reduced to 86 , whereas in the tourist area nearly 50 percent of workers were reduced (Figure 4). According to the field survey, out of 354 workers, 171 workers are found working after the COVID-19 pandemic. The cut off of a large number of workers is found in hotels and restaurants. The workers have not got subsidies from the owners after leaving the jobs. So, a large number of workers have been compelled to leave the job. The salary of the on-job workers has been found reduced. The owner of the hotels and restaurants blame that they have not got rent subsidies by the house owners as well as any other subsidies from the side of the government.

To recover the tourism industry of Pokhara, the Nepal Government in coordination with Nepal Tourism Board and other tourism organizations of Pokhara needs to develop a phase-wise approach to balance public health and economic needs according to the present situation. They could start the tourism activities by stimulating domestic travel while international travel bans are still active in Nepal. Therefore, the domestic tourism may be promoted upon the easing of travel restrictions within Pokhara.

\section{MAJOR FINDINGS}

As discussed in the section above, the study has identified the major findings, which are listed in the following points:

- The main tourist infrastructure of Pokhara are hotels, restaurants, bars, travel and travel, embroidery, tracking equipment shops, curio shops, clothing shops, boat services in Lakes, health care, air sports etc.

- Various organizations like NTB, HAAN, PTC, REBAN, NATTA, TAN is working jointly to promote tourism in Pokhara.

- The main tourist attractions of Pokhara are adventure, religious, entertainment, sightseeing, leisure, boat, research, study, wellness, sports etc. and the main touristic areas are PhewaLake, Sarangkot, Chhorepatan, Mahendra Cave, BegnasLake, Shanti Stupa, Bindiyabasini Temple etc.

- Tourism increases job opportunities. Extra work generates income from very low wages to high paid people in administration and technology, and enhances the quality of life of those involved in the tourism business of Pokhara.

- For Covid-19, "Nepal Tour- 2020" was suspended for spreading virus. Tourism is interlinked in all directions from jobs, hotels, restaurants, transport etc. 
- All trips to Pokhara have been cancelled and now a series of breaks due to the lockdown virus. The local administration is strictly applying lockdown in Kaski as positive events are increasing rapidly these days.

\section{CONCLUSION}

Pokhara is well-equipped with a variety of tourist infrastructures and tourist attractions. It is home to a large number of tourist arrivals every year. Adventure, religious, cultural, recreation, wellness, boating and other tourist activities are available here. The absurdity of natural resources can be compromised by misusing or excessive use. The Mahendra Cave and Chhorepatan areas are formed of Karst land forms and are at risk of developing sink holes. In general, tourism is considered a "smokeless" industry as hotels, restaurants and shops are the major attractions. In response to the rapid rise in global measures and increasing public concern due to COVID-19 pandemic, the government postponed the "VISIT NEPAL 2020" on 3 March 2020. The international and domestic tourism fell down in January 2020 after tourist arrivals fell to two percent compared to 2019. The majority of tourism workers have lost their jobs, which has decreased the ratio of employment. Many of them have been returned to their villages. It was happened because the hotel and restaurant entrepreneurs have not been supported by the government due to this pandemic. Curio shops, puja samagri shops, garment shops, tea shops and other businesses were badly affected. A large number of workers were also cut off and their main demand was to provide vaccines and they need to get permission to open their business quickly. It is expected that the vaccination against COVID-19 will help them return to economic activities and the restoration of the tourism industry.

\section{RECOMMENDATIONS}

In order to smoothly operate tourism activities in Pokhara after the pandemic, the following recommendations have been developed:

- High quality hotels should be established in other areas of Pokhara. Currently, it is only concentrated in the Phewa Lake area.

- New tourism activities should be explored, and the new places for paragliding should be set up as the current venue will be cancelled after the operation of Pokhara International Airport. There are many tourism spots, but there is lacking in the infrastructure development and promotion. Therefore, the concerned authority needs to provide the necessary services for the tourists.

- Government should provide financial subsidies to the tourism entrepreneurs and tourism workers to revive the tourism industry of Pokhara in the post-pandemic period.

- There should be the provision of easy refinancing and loan facilities from the financial institutions, provision of subsidies in the EMI decreasing the interest rate and quick vaccination to the people involved in tourism sectors to reduce the influence of COVID-19 pandemic.

\section{ACKNOWLEDGEMENTS}

This paper is prepared upon our mini research report submitted to the Centre for Research and Innovation (CRI), Prithvi Narayan Campus, Pokhara, which was approved in October 2021. We thank the CRI for granting us the research award. We would also like to thank Mr. Khagendra Poudel and Daya Sagar Subedi of Department of Geography, Prithvi Narayan Campus, Pokhara for their immense support and encouragement throughout this research. 


\section{REFERENCES}

Adhikari, S. (2020). Prospects of tourism in Nepal: A study of Pokhara city.

Dhakal, A. P. (2019). Potential products of tourism in Surkhet District, Nepal. Nepal Journal of Multidisciplinary Research, 2(2), 40-52.

Chaudhary, A. (2019). Impact and survival strategy for hospitality industry after COVID19. International Journal of Innovative Science and Research Technology. https://bit.ly/3o0qHnH

Jamal, T., \& Budke, C. (2020). Tourism in a world with pandemics: local-global responsibility and action. Journal of Tourism Futures, 6(2), 181-188. https://doi.org/10.1108/jtf-02-2020-0014

Kayastha, S. L. (1997). Tourism and environment in the Himalayan region. Geography and Environment, 2, Regional Issue, 31-45.

Khand, J., \& Maharjan, U.D. (2016). Understanding the nature of sustainable development in tourism: A Case study of Pokhara, Nepal. http://urn.fi/URN:NBN:fi:amk-201603153168

Kim, J. H., \& Ritchie, J. B. (2014). Cross-cultural validation of a memorable tourism experience scale (MTES). Journal of Travel Research, 53(3), 323-335. https://journals.sagepub.com/doi/abs/10.1177/0047287513496468

The Ministry of Culture, Tourism and Civil Aviation (MOCTCA). (2019). Annual Progress Book, 2076-77.

Nepal Tourism Board (NTB). (2018). Annual Tourism Statistics. Kathmandu.

Neto, F. (2003, August). A new approach to sustainable tourism development: Moving beyond environmental protection. Natural Resources Forum, 27(3), 212-222). https://doi.org/10.1111/1477-8947.00056

Paudel, N., \& Upadhyay, R., (2021). The COVID-19 Pandemic and Its Impact on Tourism Activities in Pokhara (Award No. MRF-09/CRI2021) [Unpublished manuscript]. Centre for Research and Innovation (CRI), Prithvi Narayan Campus, Pokhara, Nepal.

Prasain, S. (2021, January 09). Pokhara tourism looks beyond the coronavirus pandemic. The Kathmandu Post. https://kathmandupost.com/national/2021/01/09/pokharatourism-looks-beyond-coronavirus-pandemic

Sharpley, R. (2014). Host perceptions of tourism: A review of the research. Tourism Management, 42, 37-49. https://doi.org/10.1016/j.tourman.2013.10.007

Upreti, B. R., Sharma, S. R., Upadhaya, P. K., Ghimire, S., \& Iff, A. (2013). Making business count for peace: Reflections from tourism sector in Nepal. South Asia Regional Coordination Office of the Swiss National Centre of Competence in Research (NCCR) North-South, Department of Development Studies-Kathmandu University and Nepal Center for Contemporary Research. 